\title{
Foreign Currency Derivatives and Firm Value: Evidence from New Zealand
}

\author{
Hao Li1 ${ }^{1}$ Nuttawat Visaltanachoti' ${ }^{1}$, Robin H. Luo ${ }^{2 *}$ \\ ${ }^{1}$ School of Economics and Finance, Massey University, Auckland, New Zealand \\ ${ }^{2}$ Faculty of Business, ALHOSN University, Abu Dhabi, United Arab Emirates \\ Email: robin.h.luo@gmail.com
}

Received 12 July 2014; revised 15 August 2014; accepted 28 August 2014

Copyright (C) 2014 by authors and Scientific Research Publishing Inc.

This work is licensed under the Creative Commons Attribution International License (CC BY). http://creativecommons.org/licenses/by/4.0/

c) (7) Open Access

\begin{abstract}
The benefit of corporate hedging remains controversial. While hedging could reduce the likelihood of adverse outcome, it will incur additional costs that may offset such benefit. This study provides some evidences to resolve the debate. We examine the benefits of foreign currency derivatives usage in 134 non-financial firms listed on the New Zealand Stock Exchange. New Zealand dollar experiences relatively high volatility so it is an ideal setting to examine whether the currency derivative usage could add value to the firm. Using Tobin- $Q$ and other of its variants as a proxy of firm value, we find no evidence supporting the notion that the use of foreign currency derivatives can enhance a firm value.
\end{abstract}

\section{Keywords}

\section{Currency, Derivatives, Risk Management}

\section{Introduction}

Corporate hedging, commonly referred to risk management, is actively practiced in both large and small economies (Prevost, Rose, \& Miller, 2000), however, the question "Why do firms hedge?” is still asked daily. There are two schools of theory that demonstrate why firms use corporate hedging. One is based on owner's diversification motives or corporate managers' personal utility maximisation. It suggests that the main purpose of corporate hedging is to reduce the likelihood that managers will suffer from adverse outcomes from uncertainties. The other is based on shareholder value maximisation. It implies that corporate hedging can reduce the likelihood that firms will encounter financial difficulties. By hedging those possibilities, firms could improve their ability to finance all of their profitable investment opportunities, hence maximising shareholders value.

*Corresponding author. 
In contrast, there are also reasons why firms do not hedge. Transaction costs of hedging, such as commissions paid to dealers, bid-ask spread and transaction fees charged by OTC or stock exchange, are the first concern. Secondly, in order to accomplish the purpose of hedging, firms have to evaluate the trade-off between costs and benefits of any particular hedging strategy. Such evaluation requires expensive financial professionals to participate and is time-consuming. Moreover, hedging strategies, especially hedging with derivatives, involve complex transactions; firms must frequently monitor those transactions and implement internal control of those transactions. Because derivatives are risky, any inappropriate transaction that violates hedging objectives could bring about serious financial problems. Finally, it may complicate firms' financial reports. Preparations and adjustments for tax and accounting consequence of derivatives hedging have to be implemented and they bring extra cost.

Most of the previous empirical studies are based on U.S. or European multinationals and evidence from other geographic areas is rarely found. Also, there are contradictable results from previous literatures ${ }^{1}$ with regards to the value added effect of hedging on firm market value. This study aims to examine whether the use of foreign currency derivatives (FCDs) can cause higher firm market value within New Zealand. Findings of this study may contribute New Zealand experience to the existing empirical literatures.

New Zealand is a relatively small, deregulated economy with few barriers to trade. Traditionally, the New Zealand economy has been based on a foundation of exports from its very efficient agricultural system and highly relied on the revenue from this. For example, in 2000, exports (imports) of goods and services comprised approximately $36 \%$ (35\%) of $\mathrm{GDP}^{2}$, respectively. In comparison, exports (imports) for the US comprised only $11 \%(15 \%)$ of $\mathrm{GDP}^{3}$. Interest and exchange rate volatility is relatively high in New Zealand compared to the US and elsewhere (Berkman \& Bradbury, 1996). During the past seven years, New Zealand companies, especially exporters, have been experiencing extremely high foreign exchange volatility. The currency fluctuations have given any low margin export company managers grey hairs. Worrying about the exchange rate has taken valuable time away from developing new overseas markets. Mike Houlahan, director of foreign exchange specialist Tuatara management, says the foreign exchange risk makes the difference of whether the company is going to make a profit or loss.

Appendix 1 shows the graph of volatility of the New Zealand dollar from 1991 to 2007. The volatility spread of the dollar varies from $0.2 \%$ to nearly $1.6 \%$. From 2000 to 2007, the variation of the volatility percentage is particular larger than that in prior periods. Thus, foreign exchange risk exposure is inevitable for New Zealand firms. The exchange rate movements not only affect firm's future cash flows, but also affect the discount rate employed to value those future cash flows. Bartov, Bodnar, and Kaul (1996) conclude that there is an increase in the variability of equity returns following the period of increased exchange-rate variability. The authors suggest that the increase in exchange-rate fluctuations is an indication of an increase in the riskiness of the multinationals' cash flows. Both future cash flows and the discount rate are two major elements that are widely used by financial professionals to value a firm's exchange rate exposure, which plays an important role in altering investors' expectations on the market value of a firm. Therefore managing foreign exchange exposure becomes a primary mission for risk management practice in New Zealand.

Although other types of derivatives may have the same effect as currency derivatives, in this study, the use of FCDs is chosen to be the proxy for corporate hedging. There are three reasons why currency derivatives are focused on: 1) by considering the research target of this study, exchange rate risks have the premier position for New Zealand firms. It is practical to isolate it from other common risk factors that may affect firm market value; 2) previous empirical studies have shown mixed results on the effect of using other derivatives, such as commodity or interest rate derivatives. Tufano (1996) finds that the motivation for managers to use commodity derivatives is manager's risk aversion, which hardly adds value to a firm. In contrast, Haushalter (2000) finds that the use of commodity derivatives is related to the reduction of expected bankruptcy costs, which may add value to a firm. For hedging with interest rate derivatives, Visvanathan (1998) finds that using interest rate derivatives may he caused by value increasing strategies; 3) most firms that use other types of derivatives also use currency derivatives, since currency derivatives are considered to be the most widely used derivatives for risk management practitioners.

\footnotetext{
${ }^{1}$ Allayannis and Weston (2001) and Guay and Kothari (2003).

${ }^{2}$ Sources: Statistics New Zealand: http://www.stats.govt.nz New Zealand; Foreign Trade Statistics, US census Bureau:

http://www.census.gov/foreign-trade/www/index.html

${ }^{3}$ Source: New Zealand Herald, Page B1, "Exporters Ready for Dollar Deals” (26 $6^{\text {th }}$ August 2007).
} 
Tobins Q is used to capture firm market value in this study. Tobin’s Q, which was developed by James Tobin, compares the value of a company given by financial markets with the value of a company's assets. It is calculated by dividing the market value of a company by the replacement value of its assets (Blose \& Shieh, 1997). When it is computed for new investment only, it is referred to the marginal Q. When it is calculated for all of a firm's assets, it is referred to the average Q (also known as simple Q). If the market value of a firm is solely reflected by its recorded assets, $Q$ will equal 1 . If $Q$ is greater than 1 , the market value of a firm is greater than the cost to replace a firm's assets and implies that this firm's stock is overvalued. If $\mathrm{Q}$ locates between 0 and 1 , the market value of a firm is less than its asset replacement cost, which suggests that the stock is undervalued. High $Q$ values encourage firms to invest more in capital because they are worth more than the price they paid.

The rest of this study is structured as follows: Section 2 provides a literature review. It further demonstrates risk management theories with support from prior studies, and describes the mixed findings from previous empirical studies. Section 3 describes how the new cross sectional target dataset is built, how the control variables are decided and the hypothesis development. Based on the newly built target dataset, various tests are carried out to investigate the relationship between the use of FCDs and firm's market value in Section 4. Univariate tests are used to test the two sub-hypotheses, thereby testing the main hypothesis. Multivariate tests are utilised to further test the main hypothesis by considering the effect of control variables. Then, robustness checks are used to ensure that different methodologies of Q measurement do not significantly alter the earlier test results. Finally, Section 5 concludes.

\section{Literature Review}

There are two schools of theory on why firms hedge. The first school of theory is that the incentive of managers to maximise their personal utility functions is the reason for them to partake in hedging activities. Stulz (1984), and Smith and Stulz (1985) state that risk averse managers will actively engage in hedging for the following reasons: First, their wealth and human capital are concentrated in the corporations they work for. Second, they find the cost of hedging on their own account is higher than the cost of hedging at the corporation. Even though shareholders can hedge on their own, DeMarzo and Duffie (1995) find that hedging is optimal when managers have private information on the firm's expected profits. They also argue that outside investors may take hedging as an indicator to evaluate corporate managerial ability. Finally, Mian (1996) and Tufano (1996) find strong evidence that supports the manaerial risk aversion theory, because those managers who hold more stock tend to undertake more hedging activities. According to this school of theory, hedging should not affect firm market value.

The other school of theory is the shareholder value maximisation theory, which states that corporations undertake hedging activities in order to reduce the various costs caused by high volatility of cash flows. Previous literature provides four different aspects of explanation: 1) taxes; 2) financial distress costs; 3) costly external financing; and 4) debt capacity.

First, Mayers and Smith (1982), and Smith and Stulz (1985) argue that hedging may be motivated by tax incentives. For example, when corporations face a convex tax function hedging could help them reduce expected taxes. Second, Mayers and Smith (1982), and Smith and Stulz (1985) also state that hedging reduces the cost of financial distress. Dolde (1995) reports a positive and significant relation between hedging and leverage, which is consistent with the theory that hedging helps reduce financial distress. By examining the use of interest rate swaps by S \& P 500 non-financial firms, Visvanathan (1998) finds similar evidence too. Haushalter (2000) examines the commodity hedging activities of firms in the oil and gas industry and found evidence consistent with theories of costs of financial distress. Thirdly, Froot, Scharfstein and Stein (1993) state hedging may help relieve the underinvestment problem. For example, when corporations have to make strategic decisions regards to several growth opportunities, hedging can help them decide whether to adopt the more expensive external financing or take internally generated funds.

This kind of problem appears especially when investment opportunities are negatively correlated with cash flows. Nance et al. (1993) find that hedging firms have greater growth opportunities, which is consistent with the theory that hedging mitigates the potential underinvestment problems. By using a sample of Fortune 500 firms, Geczy, Minton and Schrand (1997) examine currency hedging activities. They find that the use of currency derivatives is directly related to the amount of research and development (R \& D) expenditures, which is also consistent with the use of hedging to reduce underinvestment Droblems. Finally, Leland (1998) claims 
hedging can raise a firm's debt capacity, thereby generating greater tax advantages from greater leverage. Graham and Rogers (2002) provide evidence that tax convexity does not seem to be a factor in the hedging decision, which conflicts with the first aspect of explanation. However, they do find that hedging companies have better debt capacity.

There are sound theories that explain why corporate managers actively hedge. However, support for value maximisation theories is mixed. Mian (1996) reports that the only reliable observation is that hedging firms tend to be larger. Moreover, Tufano (1996) examines the hedging activities of gold mining firms and finds no support for the value maximisation theory. More recently, researchers have been examining the direct relation between firm value and hedging. Allayannis and Weston (2001) provide the first related evidence. They directly test the relationship between firm market value and the use of FCDs. Using a sample of 720 large non-financial firms between 1990 and 1995, they found that the market value of firms that use FCDs, on average, is 5\% higher than firms that do not undertake hedging. This hedging premium is statistically and economically significant. It added an average of almost S200 million for firms using FCDs with a median market value of about US4 billion. Allayannis et al. (2004) and Bartram et al. (2004) also have similar results, which show firms that used derivatives have a higher market value. Graham and Rogers (2002) find that derivatives induced debt capacity increases firm value by $1.1 \%$ on average. The value-added effects from these researches are material, but the validity of these results is questioned by Guay and Kothari (2003). Guay and Kothari (2003) analyse the economic effects of derivatives positions for a sample of 243 large non-financial derivative users. They concluded that potential gains on derivatives are no more than S15 million in cash and S31 million in value, and they believe it cannot possibly have an effect of the magnitude claimed with such a small hedging premium. There are two interpretations given by Guay and Kothari (2003) for the economic effect: First, the observed increase in market values is driven by other risk management activities, for example, operating hedges that are value enhancing and positively correlated with using derivatives. Second, they believe that those results are spurious. Brown (2001), from another perspective, examines the currency hedging operations of a U.S. based manufacturing firm. He finds that foreign exchange hedging is an integral part of firm operations. However, the firm has no clear rationale foi hedging. Additionally, by investigating U.S. gold mining firms, Brown, Crabb and Haushalter (2006) find no evidence that hedging improves firm's operating or financial performance.

All of these previous empirical studies show mixed results. They either stand in favour of risk management theories or question its validity. However, nearly all of these empirical results are limited to the management of foreign currency risk for large U.S. multinationals. Such firms have nontransparent risk exposures. It is not clear whether this hedging premium exists for other types of markets, such as New Zealand. In this study, the focus group is on New Zealand firms, and the question of whether the use of FCDs can cause higher firm market value within New Zealand is examined.

\section{Data}

Cross sectional analysis is the methodology for this study. Since there is no database that fully fits the objective of this study, a brand new dataset has to be created in order to serve this study. Annual reports of all non-financial firms that were listed on the New Zealand Stock Exchange in 2007 are collected from the IRG ${ }^{4}$ online database. The 2007 annual reports provide the most up to date financial information of firms. According to NZ IFRS 7, all listed firms have been required to disclose their use of derivatives in the footnotes (also known as the Notes to the Financial Statement) of their annual reports. Thus, collecting detailed information in regards to firms' use of derivatives becomes possible. All financial firms are not included in the new dataset. The purpose of using currency derivatives by financial firms may not only be hedging, instead, derivatives may be part of their products or be used for speculating. Additionally, several commercial banks that are listed in the exchange are FCDs market makers, so they are not included in the new dataset either. Since this study focuses or whether hedging with currency derivative can add value to firm market value, eliminating certain disturbances is necessary'. Because of the unique status of the New Zealand economy, there will not be any restrictions on firm asset amount with regards to the size consideration. Data from all 134 non-financial listed firms are used. Annual reports of each of these 134 non-financial listed firms will be used as a basic information source to build the target dataset.

4http://www.irg.co.nz/ 
In the Data Description section, most data is from the original annual reports. The two major accounting figures sources are firms' Statement of Financial Performance and Statement of Financial Position. Since quite a lot of firms have overseas subsidiaries, only information from consolidated statements is relevant. For example, if a firm discloses both group and subsidiaries total assets, only group total assets book value is selected to represent the firm. The following data is from the Statement of Financial Position: a) Total Assets; b) Fixed Assets (also presented as non-current assets); c) Inventory (the closing book value of inventory is used); d) Debt (it is equal to the book value of total liabilities); Shareholders' Equity. Other data is from the Statement of Financial Performance: 1) Net Income (it is the net income after tax, interest and dividend, which attributes to shareholders); 2) Total Sales (also presented as Revenue, Sales or Operating Revenue). Another important information source in the annual report is the Notes to the Financial Statement. Since information in the Statement of Financial Performance is very general, detailed accounting figures can only be found in the Notes to the Financial Statements. R \& D expenses and Advertising expenses can be found from the footnotes that extend the expenses accounts of the Statement of Financial Performance. Advertising expenses is also commonly called promotions or marketing expenses by New Zealand firms. One part of the Notes to the Financial Statements is called Segmental Information, or simply Segment. It shows firms’ industry segment and geographic segment. Most firms disclose their foreign sales details in this part. Take Air New Zealand's 2007 Annual Report as an example $e^{5}$ Air New Zealand listed its revenue based on different geographic segments and therefore, it is easy to find out the amount of foreign sales they make in any one particular foreign country or area. The details of capital expenses normally come from two sections of the Notes to the Financial Statements. One section is the notes for general expenses and the other section is called Commitment. Market value of equity data for each firm is collected from the global financial database ${ }^{6}$.

In the Derivatives Use section, whether firms are using FCDs to hedge is recorded. Commonly, two parts of firms' annual reports disclose its risk management status, which are Statement of Accounting Policies and the Financial Instrument section of the Notes to the Financial Statements. In the Statement of Accounting Policies, firms will explicitly describe their purposes of using derivatives and what kinds of exposure they are facing. The purpose of using derivatives for each firm must be clarified since this study aims to investigate whether hedging can have value added effect for firms. If firms use derivatives to speculate, the data in turn will not be useful. Take Fisher \& Paykel Appliances as an example, in its Statement of Accounting Policies, they state that "[t]he Group has various financial instruments for the purpose of reducing its exposure to fluctuations in foreign currency exchange rate..."7 From this quoted description, it is clear that the purpose of using financial instrument for Fisher \& Paykel Appliances is to reduce its foreign exchange exposure, instead of speculating the future foreign exchange movement. The Statement of Accounting Policies of each firm, thereby, is carefully examined to make sure that not only hedgers are pointed out, but also speculators. There is no speculator has been found from this dataset. According to this, firms hedging with FCDs are considered hedgers, while firms not hedging with FCDs are considered non-hedgers. In the Financial Instrument section of the Notes to Financial Statements, firms disclose the details of financial derivatives they use, such as the derivative category, notional values, additional restrictions on contract and contract maturities ${ }^{8}$. Although hedging activities are found to be more prevalent in larger firms due to economies of scale and high fixed costs of establishing risk management programs, it is also expected to be found in smaller firms that are more likely to experience financial distress. Foreign exchange forward contract, foreign currency option and foreign currency forward contract are most commonly used by New Zealand firms and are recognised as FCDs. Quite a few firms use foreign currency swap. Although the reported magnitudes of foreign currency swap were not comparable with the magnitudes of foreign currency forward contract, swaps users are still recorded as FCDs hedgers. Appendix 3 presents the firms' FCDs using details. The Firms column represents all listed non-financial firms sorted in ascending order: the Statement column shows the reference of financial instruments; the F-instrument column shows what kinds of FCDs each firm is using. Where there are blank cells in all three columns, it shows that the 2007 annual report for that particular firm is not available. Where there are only blank cells in the F-instruments column, it shows that either the firm does not use any financial instrument or the firm uses other financial instruments rather than FCDs.

Most data is calculated from figures obtained from the Data Description section, but information regarding

\footnotetext{
${ }^{5}$ See 2007 Annual Report of Air New Zealand. page 35. Segmental Information.

${ }^{6}$ https://www.globalfinancialdata.com/index.html

${ }^{7}$ See 2007 Annual Financial Report for Fisher \& Paykel Appliances, page 44.

${ }^{8}$ See example from 2007 Annual Financial Report for Fisher \& Paykel Appliance, page 60, note 25
} 
dividend dummy and Diversification dummy has to be extracted from annual reports. Dividend payout details can be found in the Statement of Financial Performance. Dividend dummy is equal to 1 if the firm has dividend payout in 2007, it equals 0 if there is no dividend payout at all. Diversification details can be also found in the Segmental Information section of the Notes to Financial Statements. Diversification dummy is equal to 1 if the firm operates in more than one business segment and 0 otherwise.

Statistics summary is presented in Table 1 . There are 134 non-financial firms that fall under the criteria of

Table 1. Statistics summary. (a) All Firms; (b) Firms with Foreign Sales >0; (c) Firms with Foreign Sales $=0$.

\begin{tabular}{|c|c|c|c|c|c|c|}
\hline & $\mathrm{N}$ & Mean & Median & Std. Dev. & 10th Percentile & 90th Percentile \\
\hline \multicolumn{7}{|l|}{ Sample Description } \\
\hline Total Assets (mil \$) & 134 & 1039 & 104 & 4243 & 5 & 1892 \\
\hline Total Sales (mil \$) & 134 & 704 & 76 & 2727 & 3 & 1377 \\
\hline Foreign Sales Dummy & 134 & 0.46 & 0.00 & 0.50 & 0 & 1 \\
\hline Foreign Sales/Total Sales & 134 & 0.21 & 0.00 & 0.32 & 0.00 & 0.75 \\
\hline Market Value Equity (mil \$) & 134 & 1232 & 74 & 6053 & 10 & 2155 \\
\hline Market Value Debt and Equity (mil \$) & 134 & 1833 & 151 & 8823 & 14 & 3399 \\
\hline \multicolumn{7}{|l|}{ Derivatives Use } \\
\hline FCD Dummy & 134 & 0.48 & 0.00 & 0.50 & 0.00 & 1.00 \\
\hline Tobin’s Q & 134 & 2.45 & 1.66 & 2.67 & 0.98 & 3.90 \\
\hline \multicolumn{7}{|l|}{ Control Variables } \\
\hline Return on Assets & 134 & -0.07 & 0.04 & 0.52 & -0.46 & 0.17 \\
\hline Growth (Capital Exp./Sales) & 134 & 2.22 & 0.00 & 19.45 & 0.00 & 0.08 \\
\hline Debt to Equity Ratio & 134 & 1.20 & 0.79 & 2.40 & 0.18 & 2.67 \\
\hline R\&D/Total Assets & 134 & 0.05 & 0.00 & 0.34 & 0.00 & 0.02 \\
\hline Advertising/Total Assets & 134 & 0.01 & 0.00 & 0.02 & 0.00 & 0.00 \\
\hline Dividend Dummy & 134 & 0.64 & 1.00 & 0.48 & 0.00 & 1.00 \\
\hline Diversification Dummy & 134 & 0.37 & 0.00 & 0.49 & 0.00 & 1.00 \\
\hline
\end{tabular}

\begin{tabular}{ccccccc}
\hline & \multicolumn{7}{c}{ (b) } & & & \\
& $\mathrm{N}$ & Mean & Median & Std. Dev. & 10th Percentile & 90th Percentile \\
\hline Sample Description & & & & & & \\
Total Assets (mil \$) & 41 & 716 & 135 & 1661 & 5 & 1739 \\
Total Sales (mil \$) & 41 & 665 & 132 & 1410 & 4 & 0.88 \\
Foreign Sales/Total Sales & 41 & 0.44 & 0.38 & 0.32 & 0.03 & 1650 \\
Market Value Equity (mil \$) & 41 & 694 & 103 & 1571 & 23 & 3387 \\
Market Value Debt and Equity (mil \$) & 41 & 1091 & 173 & 2453 & & 1.00 \\
Derivatives Use & & & & & 0.03 & 3.97 \\
FCD Dummy & 41 & 0.59 & 1.00 & 0.50 & 0.00 & 0.92 \\
Tobin's Q & 41 & 2.43 & 1.73 & 1.91 & & \\
\hline
\end{tabular}

(c)

\begin{tabular}{ccccccc}
\hline & $\mathrm{N}$ & Mean & Median & Std. Dev. 10th Percentile 90th Percentile \\
\hline Sample Description & & & & & & \\
Total Assets (mil \$) & 46 & 1327 & 81 & 5636 & 4 & 1920 \\
Total Sales (mil \$) & 46 & 739 & 57 & 3527 & 676 & 10 \\
Market Value Equity (mil \$) & 46 & 1711 & 41 & 8205 & 12 & 3208 \\
Market Value Debt and Equity (mil \$) & 46 & 2494 & 83 & 11,936 & & 12 \\
\hline
\end{tabular}


this study. Panel A presents samples of all 134 non-financial firms. 47 of these firms' 2007 annual reports are not available, but they will be left in the dataset and recorded as "N/A". After the dataset is split into firms with foreign sales and firms without foreign sales, Panel B and Panel C represent 41 firms with foreign sales and 46 firms without foreign sales respectively. Total sales and total assets are recorded according to their book value. Foreign sales dummy equals I if the firm has foreign sales, or it equals 0 if the firm does not have any foreign sales. Firms' market value of equity is obtained from the global financial database. It is hard to obtain or estimate firms' market value of debt. So, the market value of debt and equity are simply obtained by adding the book value of debt to the market value of equity. FCDs dummy equals 1 if the firm reports any usage.

There are different editions of Tobin's Q. The Q used in this study is simple Q, which is the market value of debt and equity divided by the book value of total assets. Robustness checks in section 4 check if different editions of Q could alter the research results. Return on Assets is the ratio of net income over the book value of total assets. Growth opportunities are represented by the ratio of capital expenditure to total sales. Debt to equity ratio equals the book value of debt divided by total shareholders' equity. Dividend dummy equals 1 if the firm has dividend payout in 2007 and it equals 0 if there is no dividend payout at all. Diversification dummy equals 1 if the firm operates in more than one business segment and 0 otherwise.

Since 47 of these selected annual reports of non-financial firms are not available, data from 87 non-financial firms are viable. 134 firms are sorted in ascending order and firms without available data are left as blank cells when multivariate tests are implemented. The sample has a mean value of S1039 million for total assets and mean value of 704 million for total sales. New Zealand is an export orientated economy, but the ratio of foreign sales over total sales only shows a mean value of 0.21 . The mean value of the FCDs dummy is nearly 0.5 which may imply nearly half of the listed firms are actively hedging with currency derivatives in a statistics view. The mean value of Tobin's Q is 2.45 while its standard deviation is 2.67. It implies that $11.11 \%$ of $Q$ will exceed 8, which is very unpractical. For example, A2 Corporation has a Q of 10.5. BLIS Technologies has a Q of 11.3 and Pacific Edge Biotech has a Q of 18.24. However, most of these high Q firms fall in the industry of biotechnology, pharmaceutical and IT, which are believed to have peat potential. Interestingly, the mean value of return on assets is negative 0.07 and the median value is 0.04 which is still close to zero. Nearly $27 \%$ of these selected firms faced loss in 2007. One possible reason could be the rising New Zealand dollar, which directly or indirectly causes firms to suffer. The mean value of advertising over total assets is close to zero since only $7 \%$ of these firms disclose their advertising costs separately.

Business commercials are vital for sales no matter whether national or international. Even though the proportion of using advertising in New Zealand is small, it is still considered one control variable that could affect firm market value. Approximately $37 \%$ of the selected firms are diversified across different industrial segments, which is much smaller than the ratio in the U.S ${ }^{9}$. The target dataset is divided into two groups, which are presented by Panel B with foreign sales and Panel C without foreign sales. $46 \%$ of the selected firms have foreign sales, which have a higher mean value of FCDs dummy than firms without foreign sales. It implies that firms with foreign sales more actively use currency derivatives to hedge their risk exposure. The mean value of Tobin's Q from Panel B and Panel C are nearly the same, while firms with foreign sales hedge more actively than others. But standard deviation of Q from Panel B is slightly higher than Q from Panel C.

\subsection{Control Variables}

In order to test the association between hedging with FCDs and market value of a firm, effect of all other variables that could possibly affect firm market value $(\mathrm{Q})$ must be eliminated. In the following section, variables that are controlled in the multivariate tests are described with reasonable theoretical support.

Size: Large firms always launch a larger amount of initial investment for any project they implement compared with small firms that expose themselves to a higher scale of cost if the proposed project fails. Thereby, large firms are more likely to hedge proactively. Meanwhile, larger firms benefit from both economic of scale and economic of scope, which give them more credit on project success compared with their small size competitors. Pletzman (1977) provides arguments for the fact that size does lead to higher efficiency. Mueller (1987) similarly proclaims that, in the U.S., lager firms have higher reported accounting profits. The total assets spread of the sample dataset is large. Log of total assets is used to reduce this large spread and to reduce the size effect.

Profitability: Firms' ability to generate profit is one of the most important considerations when investors are

${ }^{9}$ According to Allayannis and Weston (2003), 63\% of U.S. non-financial firms arc diversified across different industrial segment. 
making their investment decision. Risk-averse investors would prefer to pay more for profitable firms than firms with operating loss. Therefore, firms that are more profitable will have higher Q. Using ratios is one effective way to control the magnitude of firms' profitability. Thus, the ratio of return on assets is used, which is represented by the net income after tax and dividend divided by the average of total assets.

Investment Growth: There are three control variables that fall under this investment growth section. Myers (1977), Smith and Vatts (1992) and Froot, Scharttein and Stein (1993), argue from a different angle. That firms' future investment opportunities are one of the major determinants of firms' value. Geczy, Minton and Schrand (1997) provide empirical evidence that hedgers have a better chance of bigger investment opportunities. Thus, controlling firms' investment growth is necessary. According to Yermack (1996) and Servaes (1996), the ratio of capital expenditures over total sales is used as one variable to control investment growth effect. Morck and Yeung (1991) use R \& D expenditure as a proxy for investment growth. R \& D creates great potential for firms' future growth, but how much a firm will spend on R \& D is largely dependent on its industry orientation and firm size. To overcome this effect, the ratio of $\mathrm{R} \& \mathrm{D}$ expenditure over total assets is used as the second control variable here. Additionally, similar to Morck and Yeung (1991), the ratio of advertising expense to total sales is used as the third control variable, since it is considered to be a proxy for customer goodwill. However, there is potential bias in using this variable. A number of firms did not disclose their advertising expense separately. Take Telecom and Briscoe for example, their commercials are played on TV nearly every night and households constantly receive their promotional flyers. Both firms did not separately report their advertising expenses. The effect of advertising on firms' future investment growth cannot be ignored. Thus, this particular control variable is still used in the multivariate tests, but with extra caution.

Industry Diversification: Williamson (1970) and Lewellen (1971) argue that industrial diversification creates value for firms. In contrast, Jensen (1986) suggests that there is adverse effect of industry diversification to firm value because of the agency problems between management and shareholders. Lang and Stulz (1994), Berger and Ofek (1995) and Servaes (1996) even provide empirical results on this negative effect of industry diversification on firms' value. A dummy variable is used to control this industry diversification effect. It equals I if the firm operates in multi-industry segments and equals 0 if the firm only operates in one industry segment.

Access to Financial Markets: The economical way of funding a project is from the inside source. If a firm pays out dividend, there will be fewer funds retained in the firm for future investing. As a result, firms have to finance the proposed project through the financial market, which costs firms a lot more in resources. It is not only more costly in terms of interest expenses. but also in the time consumed in regards to dealing with financing the proposed project from outsiders. By considering the cost to finance a project from outsourcing, firms may have to forgo a number of good investment opportunities. Thus, if a firm has dividend payout, it has more of a chance to outsource its project fund, and in turn it is expected to have lower Q. Lang and Stulz (1994) and Servaes (1996) also provide similar discussion in regards to this issue. To control a firm's ability to access the financial market, the dividend dummy will be used as a proxy. The dividend dummy is equal to 1 if the firm paid dividend in 2007 and equals 0 otherwise.

Leverage: The basic technique of valuing a firm is discounting its future expected cash flow by its cost of capital. Firms' capital structure directly affects the magnitude of this discount factor and future cash flow. Brealey, Myers and Marcus (2004) argue that debt financing has one important advantage, which is that interest the firm pays is a tax-deductible expense but equity income is subject to corporate tax. It implies that firms with debt financing may have higher Q. However, a firm faces greater risk of financial distress when it is overly financed by debt and therefore, controlling leverage is necessary. The leverage control variable is presented by the ratio of non-current liability to shareholders' equity.

Geographic diversification: Geographic diversification is also known as corporate multi-nationality. Dunning (1973) agree on the fact that multi-nationality creates value. Firms that invest directly overseas may increase their value by internalising the global market for its unique intangible assets. In contrast, Morck and Yeung (1991) and Bodnar, Tang and Weintrop (1997) proclaim that multi-nationality is positively associated with firm value although agency problems exist. Foreign sales are from the operational revenue of firms' overseas branches. Firms that have such foreign sales are considered multi-national corporations. Therefore, the ratio of foreign sales to total sales is used as a control variable to represent geographic diversification.

\subsection{Hypothesis Development}

There are 134 firms in the original dataset, but 47 of these firms' annual reports are not available. These 47 
firms' key statistics will be left as blank cells in the multivariate test, but they will be eliminated in the univariate test. The rest 87 firms are split into two groups, one with foreign sales the other without foreign sales. Firms with foreign sales through foreign operations are directly exposed to the foreign exchange rate. They have to face the risk of the exchange rate fluctuation on a daily basis. Using FCDs creates certainty, hence making firms more likely to be rewarded by higher market valuation from the market. Firms without foreign sales are not directly disturbed by exchange rate fluctuation, but exchange rate risks still indirectly affect them. For example, exporters and importers are largely influenced by foreign exchange exposure. Local retailers, even they do not have direct income from overseas, still have to face the input price fluctuation that they inherit from their suppliers. As such, it is hardly practical for local retailers to hedge foreign exchange risk. Firms without foreign sales may have different magnitudes of foreign exchange exposure compared with firms with foreign sales, or may have to face it less frequently. Also, there is a chance that some firms may even face non-material foreign exchange risk. In such situations, hedging with FCDs may not be valuable for firms without foreign sales. Thus, non-hedgers have no reason to have lower market values. By considering these complex circumstances, it is better to carry out analysis in separate groups.

Since there is mixed evidence that hedging definitely adds value to firms, the main hypothesis of this study is divided into two sets of sub-hypotheses:

1) For firms with foreign sales:

Null Hypothesis: Mean Q of hedgers is equal to mean $\mathrm{Q}$ of non-hedgers

Alternative Hypothesis: Mean Q of hedgers is greater than mean Q of non-hedgers

2) For firms without foreign sales:

Null Hypothesis: Mean $\mathrm{Q}$ of hedgers is equal to mean $\mathrm{Q}$ of non-hedgers

Alternative Hypothesis: Mean Q of hedgers is greater than mean Q of non-hedgers

\section{Analysis of FCDs and Firm Market Value}

\subsection{Univariate Tests}

The two sets of sub-hypotheses are tested in this section. The null hypothesis for firms with foreign sales implies that hedgers are indifferent to non-hedgers, as hedging with FCDs does not cause higher market valuation. The alternative hypothesis for firms with foreign sales implies that using FCDs to hedge leads to higher market valuation. For firms without foreign sales, the null hypothesis still stays in its indifferent position, while the alternative hypothesis states that hedgers are rewarded by higher market valuation.

Table 2 presents the comparison of Simple Q between hedgers and non-hedgers. Column 1 shows the mean Q of hedgers with foreign sales and column 2 shows the mean Q of hedgers without foreign sales. Column 3 and 4 show the mean $\mathrm{Q}$ of hedgers and non-hedgers respectively and firms under both columns have no foreign sales. Column 5 shows the difference of mean Q between column 1 and column 2, and column 6 shows the difference of mean Q between column 3 and column 4. Surprisingly, the difference of mean Q in both column 5 and column 4 show a negative number. This implies that hedgers either vith or without foreign sales have a lower market value than non-hedgers. This result is quite contrary to the corporate risk management theory, so it is necessary to test its statistical validity. T-test is used to test the two hypotheses because the observations in all 4 columns are less than 30.

Table 3 presents the statistics summary of the T-test. For firms with foreign sales, their T statistic is -0.8144 which is smaller than the $\mathrm{T}$ critical two-tail value (2.0687). Meanwhile, the $\mathrm{T}$ critical two-tail value is not sig-

Table 2. Comparison of simple Q: hedgers vs non-hedgers.

\begin{tabular}{|c|c|c|c|c|}
\hline & \multicolumn{2}{|c|}{ Foreign Sales $>0$} & \multicolumn{2}{|c|}{ Foreign Sales $=0$} \\
\hline & Hedgers & Non-hedgers & Hedgers & Non-hedgers \\
\hline Mean & 2.2049 & 2.7494 & 1.5168 & 3.0863 \\
\hline Std. Dev. & 1.3573 & 2.5088 & 0.5709 & 4.0083 \\
\hline $\mathrm{N}$ & 24 & 17 & 18 & 28 \\
\hline Difference in Mean (t-stat) Hedgers-Non-Hedgers & \multicolumn{2}{|c|}{-0.5445} & \multicolumn{2}{|c|}{-1.5694} \\
\hline
\end{tabular}


Table 3. T-test summary.

\begin{tabular}{ccccc}
\hline & \multicolumn{2}{c}{ Foreign Sales $>0$} & \multicolumn{2}{c}{ Foreign Sales $=0$} \\
\hline Mean & Hedgers & Non-Hedgers & Hedgers & Non-Hedgers \\
Variance & 2.2049 & 2.7494 & 1.5168 & 3.0863 \\
$\mathrm{~N}$ & 1.8422 & 6.2939 & 0.3259 & 16.0668 \\
Difference in Mean (t-stat) Hedgers-Non-Hedgers & 24 & 17 & 18 & 28 \\
\hline
\end{tabular}

nificant at the $10 \%$ level, so it is also not significant at the $5 \%$ and $1 \%$ levels. It shows that the null hypothesis, which states that there is no difference between hedgers and non-hedgers, cannot be rejected at any of the three levels. For firms without foreign sales, $\mathrm{T}$ critical two-tail value is significant at the $10 \%$ level, but it is not significant at the $5 \%$ and $1 \%$ levels. To reject the null hypothesis, $\mathrm{T}$ statistic has to be lesser than -2.0452 or larger than 2.0452. The $\mathrm{T}$ statistics for firms without foreign sales is -2.0399 . This shows that the null hypothesis cannot be rejected at the $10 \%$ level for firms without foreign sales.

One detail deserves more attention from Table 2: the mean Q of column 2 and column 4 is nearly 3. It lies just on the practical edge. Moreover, the standard deviation of mean $\mathrm{Q}$ from column 2 is nearly double the value in column 1, and the standard deviation of column 4 is 8 times larger than the same number in column 3 . Such a large jump shows that there are a certain amount of firms that have Qs greater than the practical edge. Inherently, Tobin's $Q$ has a practical value that is equal to or smaller than 3. Certain high Qs may give misleading information or even alter the test results. Therefore, a practically adjusted $\mathrm{Q}$ is used to further test the hypotheses. Firms with $\mathrm{Q}$ greater than 4 will be eliminated from the original dataset. The elimination not only includes the Q itself, but also includes all relevant data from that firm.

Table 4 presents the comparison of adjusted Q between hedgers and non-hedgers. It has the same format as Table 3. After eliminating the extreme Qs. the difference of mean Q between hedgers and non-hedgers becomes quite small, and the spread of their associated standard deviations are reduced as well. In column 5 , the mean $Q$ difference between hedgers and non-hedgers for firms with foreign sales becomes positive. This is consistent with the corporate risk management theory. In column 6, for firms without foreign sales, hedgers still have a lower mean $\mathrm{Q}$ than non-hedgers. Again, the statistical validity needs to be tested before any conclusions.

Table 5 shows the T-test summary for adjusted Q. For firms with foreign sales, the 1 critical two-tail value is not significant at the $10 \%$ level, so it is also not significant at the $5 \%$ and $1 \%$ levels. Thus, the null hypothesis cannot be rejected at any of the three levels. For firms without foreign sales, the T-critical two-tail value is also not significant at all three levels. As a result, the null hypothesis under the second group cannot be rejected either.

\subsection{Multivariate Tests}

None of the null hypotheses in each sub-hypothesis has been rejected in the univariate test. This implies that there is no difference on firm market value between hedgers and non-hedgers. However, in order to examine the relationship between the use of FCDs and firm market value, variables that impact the Q value should be controlled as discussed earlier. Thus in this section, the main hypothesis is tested using multivariate tests. The variables are controlled in the following order: 1) size, which is represented by log of total assets: 2) profitability, which is represented by the ratio of return on assets; 3 ) investment growth. which is represented by the ratio of capital expenses over sales, the ratio of $\mathrm{R} \& \mathrm{D}$ expenses to total assets and the ratio of advertising expenses over total assets: 4) industry diversification, which is represented by the diversification dummy; 5) access to financial markets, which is demonstrated by debt to equity ratio; 6) leverage, which is represented by the dividend dummy; and 7) geographic diversification, which is demonstrated by the ratio of foreign sales to total sales.

\subsubsection{Variable Validity Tests}

Before actually carrying out the multivariate test, whether each control variable is suitable for this New Zealand target dataset, needs to be tested first. Thus, in the following section, each proposed control variable and the 
Table 4. Comparison of adjusted Q: Hedgers vs. Non-hedgers.

\begin{tabular}{cccccc}
\hline & \multicolumn{2}{c}{ Foreign Sales $>0$} & \multicolumn{2}{c}{ Foreign Sales $=0$} \\
Mean & Hedgers & Non-hedgers & Hedgers & Non-hedgers \\
Std.Dev. & 2.0069 & 1.8105 & 1.5168 & 1.6857 \\
$\mathrm{~N}$ & 0.9702 & 1.0122 & 0.5709 & 0.5982 \\
Difference in Mean (t-stat) Hedgers-Non-Hedgers & 24 & 17 & 18 & 28 \\
\hline
\end{tabular}

Table 5. Adjusted Q: T-test summary.

\begin{tabular}{cccccc}
\hline & \multicolumn{2}{c}{ Foreign Sales $>0$} & \multicolumn{2}{c}{ Foreign Sales $=0$} \\
\hline Mean & Hedgers & Non-Hedgers & Hedgers & Non-Hedgers \\
Variance & 2.0069 & 1.8105 & 1.5168 & 1.6857 \\
$\mathrm{~N}$ & 0.9413 & 1.0246 & 0.3259 & 0.3578 \\
Difference in Mean (t-stat) Hedgers-Non-Hedgers & 23 & 14 & 18 & 24 \\
\hline
\end{tabular}

main dependent variable is tested by OLS regression to find their statistical validity. In order to reduce any possible technique errors, all 134 observations are included.

Table 6 presents the summary statistics of OLS regression. For each control variable, White Heteroskedasticity is controlled while processing the regression. Each control variable is listed in column 1 . Most of the control variables are statistically significant. Size, return on assets, R \& D to total assets and the diversification dummy are significant at the $1 \%$ level, which also makes them significant at the $5 \%$ and $10 \%$ levels. Advertising over total assets and dividend dummy are significant at the $5 \%$ level, which makes them also significant at the $10 \%$ level. But the ratio of capital expense to sales, debt to equity ratio and ratio of foreign sales to total sales are not significant at all three levels.

In column 2, three variables are very prominent, namely, ROA, R \& D over total assets and advertising over total assets. Only R \& D over total assets has the expected sign, while the other two have negative signs. Earlier in the investment growth section of control variable description, the cautiousness of using advertising expenses was discussed. Since a number of listed firms did not disclose their advertising expense separately, the advertising expenses for those particular firms were recorded as zero. This could create a significant bias and is shown in this OLS regression. A possible explanation for the negative ROA sign may be the fact that firm market value is largely dependent on its ability to generate future cash flow, not its current period profit. The other two variables, size and the dividend dummy, have the expected sign for coefficient like stated by Lang and Stulz (1994).

Another point of attention is that there are a number of extreme $Q$ values in the original dataset. These extreme values could affect the test, therefore certain adjustments are needed. Like in the earlier univariate test section, firms with $\mathrm{Q}$ values that are greater than 4 are eliminated and left blank cells for regression.

Table 7 has a similar format to Table 6. It presents the summary statistics of OLS regression that are generated by Eview for each control variable. White Heteroskedasticity is controlled during processing the regression. Again each control variable is listed in column 1. This time, only the ratio of capital expenses to total sales and $\mathrm{R} \& \mathrm{D}$ expenses over total assets are significant at all three levels. ROA, advertising over total assets and debt to equity ratio are significant at the $10 \%$ level. Size is significant at both the $5 \%$ and $10 \%$ levels. In column 2, all variables have the expected sign as Lang and Stulz (1994) stated, except for ROA and the ratio of advertising expenses to total assets. After eliminating the effect of extreme Q values, the magnitude of the ROA coefficient is smaller than before but still has a negative sign. Four control variables, namely, diversification dummy, dividend dummy, ratio of foreign sales to total sales and debt to equity ratio, are not significant at all three levels. This implies that all four of these control variables may not have any direct relationship with firm market value 
Table 6. Simple Q.

\begin{tabular}{ccccc}
\hline & Coefficients & T-stats & R-square & $P$-Value \\
\hline Size (log of total assets) & -1.2435 & -4.8045 & 0.2043 & 0.0000 \\
ROA & -3.5985 & -4.4953 & 0.4996 & 0.0000 \\
Growth (Capital Exp/Sales) & -0.0014 & -0.7987 & 0.0001 & 0.4267 \\
R \& D/Assets & 5.7056 & 9.1667 & 0.5203 & 0.0000 \\
Diversification Dummy & -1.2311 & -2.7136 & 0.0500 & 0.0081 \\
Advertising/Assets & -9.3772 & -2.4957 & 0.0061 & 0.0145 \\
Dividend Dummy & -1.7686 & -2.4091 & 0.1019 & 0.0182 \\
Debt to Equity & -0.0073 & -0.6169 & 0.0044 & 0.5389 \\
Foreign Sales/Total Sales & 0.6224 & 0.6057 & 0.0054 & 0.5464 \\
\hline
\end{tabular}

This Table shows the following univariate regression: $\mathrm{Q}=\beta_{0}+\beta_{1} * \mathrm{X}$ with 134 observations. T-statistics are computed from White heteroskedasticity-consistent standard errors.

\begin{tabular}{ccccc} 
Table 7. Adjusted Q. & \multicolumn{3}{c}{} \\
\hline & Coefficients & T-stats & R-square & $P$-Value \\
\hline Size (log of total assets) & -0.2567 & -3.0773 & 0.0886 & 0.0029 \\
ROA & -0.4991 & -1.8741 & 0.0390 & 0.0647 \\
Growth (Capital Exp/Sales) & 0.0027 & 4.7422 & 0.0047 & 0.0000 \\
R \& D/Assets & 19.1419 & 7.9331 & 0.1538 & 0.0000 \\
Diversification Dummy & -0.1487 & -0.8512 & 0.0084 & 0.3973 \\
Advertising/Assets & -2.5760 & -1.7372 & 0.0056 & 0.0863 \\
Dividend Dummy & -0.2519 & -1.2149 & 0.0215 & 0.2159 \\
Debt to Equity & -0.0737 & -1.8515 & 0.0358 & 0.6790 \\
Foreign Sales/Total Sales & 0.2685 & 0.8256 & 0.0099 & 0.4116 \\
\hline
\end{tabular}

This Table shows the following univariate regression: Adjusted-Q $=\beta_{0}+\beta_{1} * \mathrm{X}$ with 134 observations. T-statistics are computed from White heteroskedasticity-consistent standard errors.

for New Zealand firms. Further, the ratio of foreign sales to total sales, which represents the geographic diversification, does not have statistical significance both before and after adjusting Q. The ratio of advertising expenses to total assets still has a negative sign. Due to its uncertainty status, this ratio should not be included in the multivariate test. Therefore, five of the following control variables will not be included in the multivariate test: 1) diversification dummy; 2) dividend dummy; 3) ratio of foreign sales to total sales; 4) debt to equity ratio; and 5) ratio of adverting expenses to total assets.

Table 8 presents the summary statistics of OLS regression for the dependent variable FCD dummy. White Heteroskedasticity is controlled while processing the regression. The explanatory variable represents the dependent variable FCD dummy with respect to different Tobin's Q. One interesting factor in row (a) is that the FCD dummy has a negative sign for its coefficient. This implies that hedging with FCDs is negatively related to firm market value. This is quite contrary to the risk management theories. However, one thing should be considered, and this is that there are a number of extreme $Q$ values in the original dataset. These extreme $Q$ values could affect the multivariate test, therefore certain adjustments are needed. Like in earlier sections, firms with $Q$ values greater than 4 are eliminated and blank cells are left for regression. In row (b), the coefficient of major dependent variable FCD dummy becomes positive this time. This is consistent with the corporate risk management theory although without statistical significance. Therefore, adjusted $\mathrm{Q}$ is used in the following multivariate test with its respect dependent and control variables. 
Table 8. Main dependent variable.

\begin{tabular}{ccccc}
\hline & Coefficients & T-stats & R-square & $P$-Value \\
\hline Simple Q: FCD Dummy & -1.0490 & -1.9107 & 0.0390 & 0.0594 \\
Adjusted Q: FCD Dummy & 0.0600 & 0.3311 & 0.0014 & 0.7415 \\
\hline
\end{tabular}

This Table shows the following univariate regression: Tobin- $\mathrm{Q}=\beta_{0}+\beta_{1}{ }^{*} \mathrm{X}$ with 134 observations. T-statistics are computed from White heteroskedasticity-consistent standard errors.

\subsubsection{Multivariate Test}

Table 9 presents the summary statistics of OLS regression that are generated by Eview for the multivariate test. The dependent variable is the adjusted Q; FCD represents FCD dummy; ROA represents return on total assets ratio; Growth represents the ratio of capital expense to total sales, and $\mathrm{R} \& \mathrm{D}$ /assets represents the ratio of $\mathrm{R} \&$ $\mathrm{D}$ expenses to total assets. White Heteroskedasticity effect is controlled. Every control variable is statistically significant except for ROA. The ratio of R \& D expenses to total assets has a very strong coefficient among all variables. The coefficient of FCD dummy is greater than single OLS regression, but it still does not have any statistical significance. This is consistent with the univariate test, which shows that statistically it is not certain whether there is any association between using FCDs and firm market value.

\subsection{Robustness Checks}

The methodology used in this study defines Tobin's $Q$ as the ratio of market value of debt and equity to a firm's total assets, which is also known as simple Q. Various other methodologies are used by prior researchers to state Tobin's Q. Thereby, investigation of how sensitive our test results are to this Q measurement is necessary. In this section, two alternative measurements are constructed for robustness checks. The first alternative $Q$ measurement follows the methodology from Lewellen and Badrinath (1997), which is denoted by QL in this section. According to Lewellen and Badrinath (1997), the replacement cost of assets is calculated by adding inventories to the sum of the replacement cost of fixed assets. The replacement cost of fixed assets is estimated by the book value of non-current fixed assets after current year depreciation adjustments. The replacement cost of inventories is the closing balance of the current year's book value of inventories. Since LIFO is not allowed in New Zealand, the LIFO reserve effect does not need to be considered. The second alternative $Q$ measurement is simply calculated by market value of debt and equity divided by total sales, which is denoted by QS in this section. Again, the book value of a firm's total liability is used to represent debt value since the market value of each firm's debt is quite hard to get.

Table 10 presents the comparison of alternative Q measures. QS has the same extreme value problems like simple Q encountered in the previous section. For example, one QS is 2638 and the other QS is 281, which are very different. After eliminating these two extreme values, the mean value of QS is reduced to 4.6648. Compared with the Q used in previous tests, both QL and QS have a higher mean value and a higher standard deviation. The mean QL is nearly double the mean QS, and the mean QS is nearly double the mean Q. There is definitely a steadily increasing spread among the three alternative Q measurements. The spread of QL is much wider than the spread of QS. For instance, the 10th percentile of QL is 1.4521 but its 90th percentile rose to 25.9908.

To reduce the wide spread and make alternative Qs more centralised, the natural log of QL and QS is used. After taking the natural log of two alternative Qs, their data spread is reduced and their mean value came closer to the practical value. Table 11 presents the results of OLS regression that uses the natural log of QL as the dependent variable. The total number of observations is still 134, while White Heteroskedasticity effect is controlled. Similar to the earlier multivariate test, the dependent variable FCD dummy still does not have any statistical significance but has the expected coefficient sign. Most control variables are statistically significant except for the ratio of R\&D to total assets. Return on total assets still has a negative coefficient but with higher significance.

Table 12 presents the results of OLS regression that uses natural log of QS as the dependent variable. The total number of observations is still 134, while White Heteroskedasticity effect is controlled. Although most the control variables and dependent variable FCD dummy have opposite coefficients compared with the earlier multivariate test, nearly all of these variables including constant are not statistically significant at any of the three levels. Only the growth control variable has the expected coefficient sign and has statistical significance. 
Table 9. Multivariate OLS regression.

\begin{tabular}{cccc}
\hline & Coefficients & T-stats & $P$-Value \\
Constant & 3.4069 & 0.8867 & 0.0003 \\
FCD Dummy & 0.2134 & 0.2087 & 0.3099 \\
Size (log of total assets) & -0.2250 & 0.1155 & 0.0554 \\
ROA & -0.2443 & 0.2978 & 0.4147 \\
Growth (Capital Exp/Sales) & 0.0025 & 0.0008 & 0.0029 \\
R \& D/Assets & 16.6938 & 2.2967 & 0.0000 \\
\hline
\end{tabular}

This Table shows the following multivariate regression: Adjusted-Q $=\beta_{0}+\beta_{1} * \mathrm{X}_{1}+\ldots+\beta_{\mathrm{k}} * \mathrm{X}_{\mathrm{k}}$ with 134 observations. T-statistics are computed from White heteroskedasticity-consistent standard errors.

Table 10. Alternative Q comparison.

\begin{tabular}{cccccc}
\hline & Tobin's Q & QL & $\log (\mathrm{QL})$ & QS & $\log (\mathrm{QS})$ \\
\hline Mean & 2.4526 & 8.8082 & 0.6649 & 4.6648 & 0.3487 \\
Median & 1.6584 & 3.5082 & 0.5451 & 1.9909 & 0.2990 \\
Std. Dev. & 2.6685 & 12.1308 & 0.4742 & 8.8912 & 0.4792 \\
10th Percentile & 0.9805 & 1.4521 & 0.1620 & 0.5812 & 0.2357 \\
90th Percentile & 3.8980 & 25.9908 & 1.4148 & 11.4683 & 1.0494 \\
\hline
\end{tabular}

Table 11. Multivariate regression for QL.

\begin{tabular}{cccc}
\hline & Coefficients & T-stats & $P$-Value \\
Constant & 1.9238 & 0.4336 & 0.0000 \\
FCD Dummy & 0.0222 & 0.1159 & 0.8486 \\
Size (log of total assets) & -0.1604 & 0.0565 & 0.0057 \\
ROA & -0.3581 & 0.1723 & 0.0409 \\
Growth (Capital Exp/Sales) & -0.0011 & 0.0004 & 0.0112 \\
R \& D/Assets & -0.2353 & 0.1759 & 0.1850 \\
\hline
\end{tabular}

This Table shows the following multivariate regression: $\log (\mathrm{QL})=\beta_{0}+\beta_{1} * \mathrm{X}_{1}+\ldots+\beta_{\mathrm{k}} * \mathrm{X}_{\mathrm{k}}$ with 134 observations. T-statistics are computed from White heteroskedasticity-consistent standard errors.

Table 12. Multivariate regression for QS.

\begin{tabular}{cccc}
\hline & Coefficients & T-stats & $P$-Value \\
\hline Constant & -0.2675 & 0.4294 & 0.5351 \\
FCD Dummy & -0.0628 & 0.1010 & 0.5355 \\
Size (log of total assets) & 0.0737 & 0.0553 & 0.1859 \\
ROA & -0.3309 & 0.2009 & 0.1035 \\
Growth (Capital Exp/Sales) & 0.6762 & 0.3032 & 0.0286 \\
R \& D/Assets & 0.0803 & 0.2334 & 0.7316 \\
\hline
\end{tabular}

This Table shows the following multivariate regression: $\log (\mathrm{QS})=\beta_{0}+\beta_{1} * \mathrm{X}_{1}+\ldots+\beta_{\mathrm{k}} * \mathrm{X}_{\mathrm{k}}$ with 134 observations. T-statistics are computed from White heteroskedasticity-consistent standard errors. 
The results of the robustness checks show that both alternative $\mathrm{Q}$ measurements have similar test results as simple Q, which is used in the earlier multivariate test. In the two above OLS regressions, the two coefficients of FCD dummy are nearly zero, which have less magnitude than the earlier multivariate test. Although the FCD dummy in all three Q measures does not have statistical significance, the $P$-value of FCD dummy in the earlier multivariate test is closer to the $10 \%$ statistical significance bench mark. Statistically, no matter which kind of Q measurement methodology is used, it is not certain whether there is any association between hedging with FCDs and firm market value.

\section{Conclusion}

This study examines whether the use of FCDs can cause higher finn market value within New Zealand. A new dataset is built based on 2007 annual reports of 134 non-financial finns listed in the New Zealand Stock Exchange. Tobin's Q is used as an approximation for finns' market value.

The original dataset is separated into two groups, one with foreign sales and the other one without. The main hypothesis is divided into two sub-hypotheses based on the finns' foreign sales status, which allows the univariate tests to have a clear outline. Both null sub-hypotheses, for different reasons, cannot be rejected. The first sub-hypothesis cannot be rejected due to a lack of statistical significance. The second sub-hypothesis cannot be rejected due to the fact that T-statistics do not satisfy T-test requirements. Therefore, statistically, there is no direct relationship between the use of FCDs and firm market value for firms without foreign sales. For firms with foreign sales, statistically, it is not certain if there is any causality between the use of FCDs or firm market value either. Due to the possibility that extreme Q values in the target dataset may affect the tests results materially, adjusted Q is used to further test two-hypotheses. After eliminating Qs that are greater than 4, both null hypotheses still cannot be rejected due to a lack of statistical significance. There is a possible reason that other control variables may affect the univariate tests, so multivariate tests are utilised to further test the main hypothesis. After testing the relationship of $\mathrm{Q}$ with each control variable, five proposed control variables are eliminated from the final OLS regression. However, whether using simple Q or adjusted Q, the multivariate tests still show that there is no causality between the use of FCDs and firm market value.

In addition, by considering the possibility that different methodology of calculating Q may alter the tests results, the robustness checks are carried out. Two alternative methodologies of Q measurement are introduced. One, denoted by QL, follows Lewellen and Badrinath's (1997) methodology. The other one, denoted by QS, is simply calculated by the ratio of market value of debt and equity to total sales. After modifying extreme Qs for both measures, OLS regression is used to test whether there is any association between the use of FCDs and firm market value. Both OLS regressions have similar results to the earlier multivariate tests. These regressions show that there is no clear association between the use of FCDs and firm market value.

There is no evidence to support the value added benefits of hedging with FCDs in this study. This shows that, statistically, there is no evidence that the use of FCDs can cause higher firm market value for New Zealand firms. This finding is consistent with findings of Guay and Kothari (2003), which shows that the use of derivatives is of minor economic significance. One possible reason for this result is that the benefit of using FCDs may be offset by their high initial set up price and transaction costs. Another reason could be that of New Zealand's unique status. Only a few multinational firms list their stocks crossly in both their home country and New Zealand. Finally, since creating a new dataset takes a lot of time and effort, a single cross sectional dataset may not serve this study well. Panel datasets with more than 5 years time series data could be considered in future research to see if there is any improvement. Therefore, this study encourages further risk management empirical study with respect to this small and deregulated economy of New Zealand.

\section{References}

Allayannis, G., \& Weston, J. (2001). The Use of Foreign Currency Derivatives and Firm Market Value. Review of Financial Studies, 14, 243-276. http://dx.doi.org/10.1093/rfs/14.1.243

Allayannis, G., \& Mozumdar, A. (2004). The Impact of Negative Cash Flow and Influential Observations on InvestmentCash Flow Sensitivity Estimates. Journal of Banking \& Finance, 28, 901-930. http://dx.doi.org/10.1016/S0378-4266(03)00114-6

Bartov, E., Bodnar, G. M., \& Kaul, A. (1996). Exchange Rate Variability and the Riskiness of U.S. Multinational Firms: Evidence from the Breakdown. Journal of Financial Economics, 42, 105-132.

http://dx.doi.org/10.1016/0304-405X(95)00873-D 
Berger, P., \& Ofek, E. (1995). Diversification’s Effect on Firm Value. Journal of Financial Economics, 37, 39-65. http://dx.doi.org/10.1016/0304-405X(94)00798-6

Berkman, H., \& Bradbury, M. E. (1996). Empirical Evidence on the Corporate Use of Derivatives. Financial Management, 25, 5-13.

Blose, L. E., \& Shieh, J. C. (1997). Tobin’s q-Ratio and Market Reaction to Capital Investment Announcements. Financial Review, 32, 449-476. http://dx.doi.org/10.1111/j.1540-6288.1997.tb00434.x

Brown, G. W. (2001). Managing Foreign Exchange Risk with Derivatives. Journal of Financial Economics, 60, 401-448. http://dx.doi.org/10.1016/S0304-405X(01)00049-6

Brown, G. W., Crabb, P. R., \& Haushalter, D. (2006). Are Firms Successful at Selective Hedging? The Journal of Business, 79, 2925-2949. http://dx.doi.org/10.1086/508004

DeMarzo, P., \& Duffie, D. (1995). Corporate Incentives for Hedging and Hedge Accounting. Review of Financial Studies, 95, 743-771. http://dx.doi.org/10.1093/rfs/8.3.743

Dolde, W. (1995). Hedging, Leverage, and Primitive Risk. Journal of Financial Engineering, 4, 187-216.

Exporters Ready for Dollar Deals (2007). New Zealand Herald. p. B1.

Froot, K., Scharfstein, D., \& Stein, J. (1993). Risk Management: Coordinating Corporate Investment and Financing Policies. Journal of Finance, 18, 1624-1658.

Geczy, C., Minton, B., \& Schrand, C. (1997). Why Firms Use Currency Derivative? Journal of Finance, 52, 1324-1354. http://dx.doi.org/10.1111/j.1540-6261.1997.tb01112.x

Graham, J., \& Rogers, D. (2002). Do Firms Hedge in Response to Tax Incentives? Journal of Finance, 57, 815-839. http://dx.doi.org/10.1111/1540-6261.00443

Guay, W., \& Kothari, S. P. (2003). How Much Do Firms Hedge with Derivatives? Journal of Financial Economics, 80, 423461. http://dx.doi.org/10.1016/S0304-405X(03)00179-X

Haushalter, G. D. (2000). Financing Policy, Basis Risk, and Corporate Hedging: Evidence from Oil and Gas Producers. The Journal of Finance, 55, 107-152. http://dx.doi.org/10.1111/0022-1082.00202

Leland, H. (1998). Agency Cost, Risk Management, and Capital Structure. Journal of Finance, 53, 1213-1243. http://dx.doi.org/10.1111/0022-1082.00051

Mayers, D., \& Smith, C. (1982). On the Corporate Demand for Insurance. Journal of Business, 55, 281-296. http://dx.doi.org/10.1086/296165

Mian, S. (1996). Evidence on Corporate Hedging Policy. Journal of Financial and Quantitative Analysis, 31, 419-439. http://dx.doi.org/10.2307/2331399

Nance, D., Smith, C., \& Smithson, C. (1993). On the Determinants of Corporate Hedging. Journal of Finance, 18, $267-284$. http://dx.doi.org/10.1111/j.1540-6261.1993.tb04709.x

Prevost, A. K., Rose, L. C., \& Miller, G. (2000). Derivatives Usage and Financial Risk Management in Large and Small Economies: A Comparative Analysis. Journal of Business Finance \& Accounting, 27, 733-759. http://dx.doi.org/10.1111/1468-5957.00332

Servaes, H. (1996). The Value of Diversification during the Conglomerate Merger Wave. Journal of Finance, 51, 12011225. http://dx.doi.org/10.1111/j.1540-6261.1996.tb04067.x

Smith, C., \& Stulz, R. (1985). The Determinants of Firms’ Hedging Policies. Journal of Finance and Quantitative Analysis, 20, 391-405. http://dx.doi.org/10.2307/2330757

Stulz, R. (1984). Optimal Hedging Policies. Journal of Financial and Quantitative Analysis, 19, 127-140. http://dx.doi.org/10.2307/2330894

Tufano, P. (1996). Who Manages Risk? An Empirical Examination of Risk Management Practices in the Gold Mining Industry. Journal of Finance, 51, 1097-1137. http://dx.doi.org/10.1111/j.1540-6261.1996.tb04064.x

Visvanathan, G. (1998). Who Uses Interest Rate Swaps? A Cross-Sectional Analysis. Journal of Accounting, Auditing and Finance, 13, 173-200. 


\section{Appendix 1}

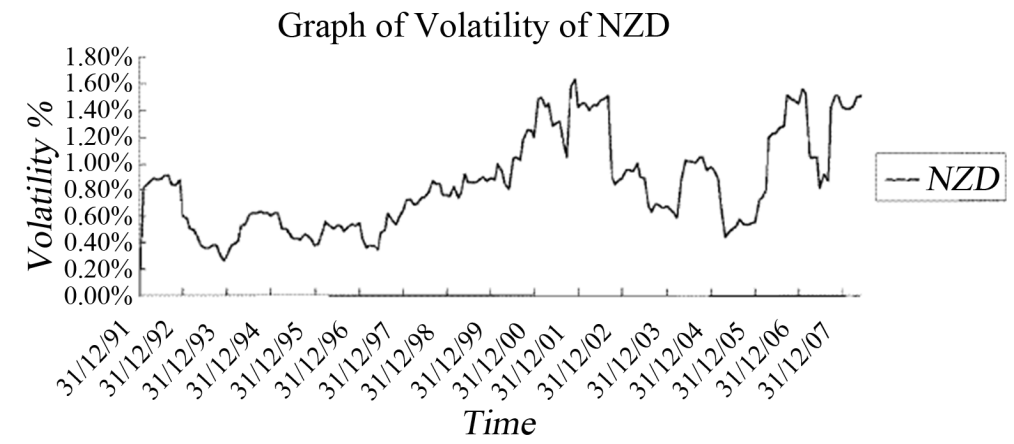

Note: Monthly New Zealand TWI price is extracted from the global financial database. The covering period is from 31th December 1991 to 31st December 2007. Monthly returns of New Zealand TWI, thereby, are generated for the selecting period. The percentage of volatility is calculated by the standard deviation of every 12 months New Zealand TWI returns. Each percentage of volatility is generated by moving one moth forward for every 12 month interval. 
Scientific Research Publishing (SCIRP) is one of the largest Open Access journal publishers. It is currently publishing more than 200 open access, online, peer-reviewed journals covering a wide range of academic disciplines. SCIRP serves the worldwide academic communities and contributes to the progress and application of science with its publication.

Other selected journals from SCIRP are listed as below. Submit your manuscript to us via either submit@scirp.org or Online Submission Portal.
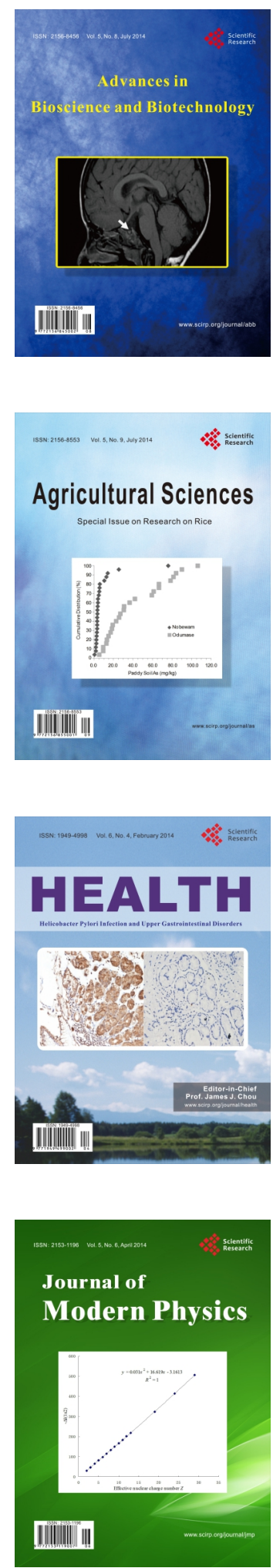
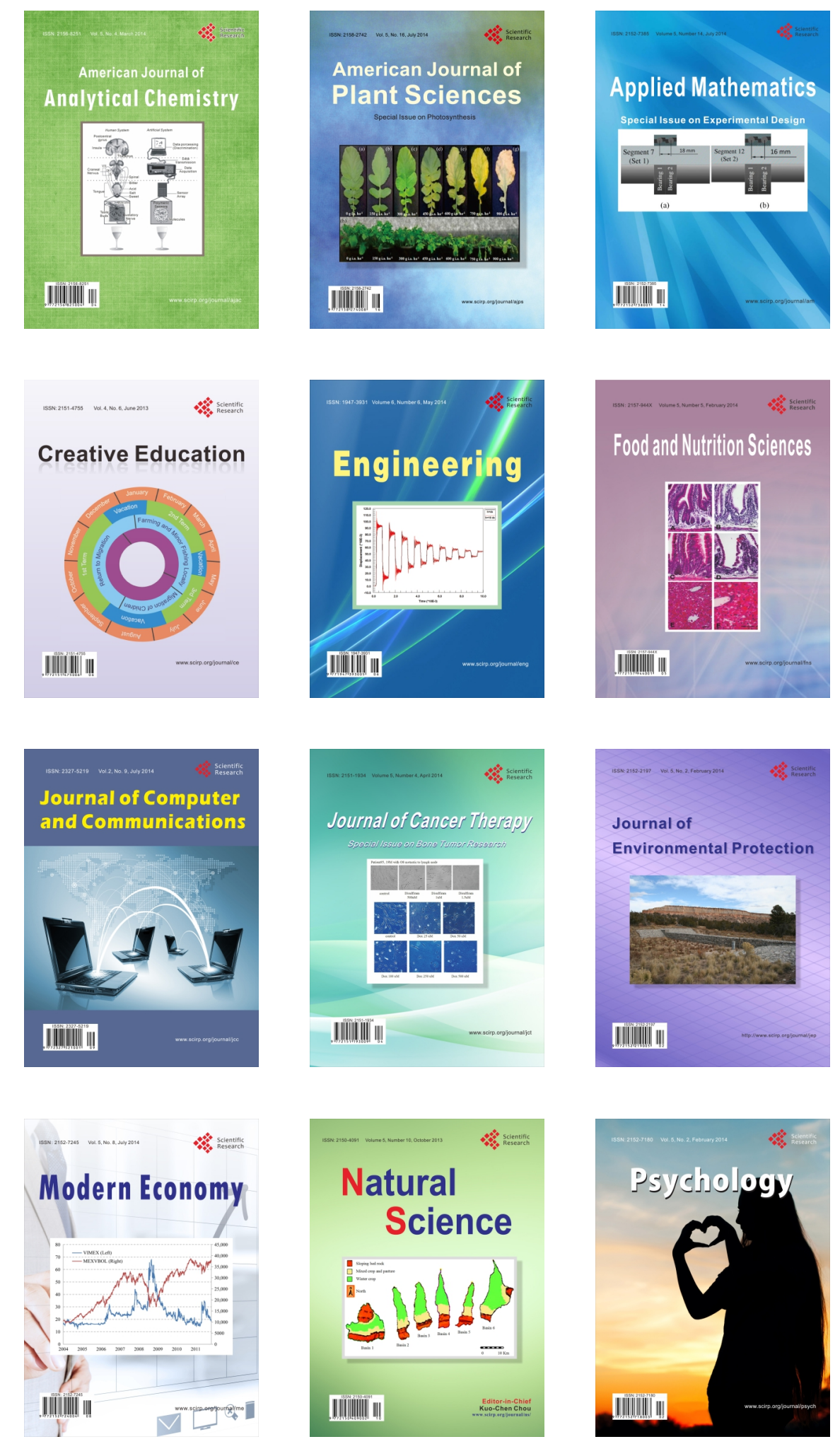